\title{
Standard Business Reporting (SBR) Adoption in Australia, Critically Acclaimed, Box Office Flop: Constructivist and Ecological Rationalities in Information Systems (IS) Adoption
}

Arif Perdana

Singapore Institute of Technology

Arif.Perdana@Singaporetech.edu.sg

\author{
Alastair Robb \\ UQ Business School, \\ University of Queensland \\ Fiona Rohde \\ UQ Business School, \\ University of Queensland \\ TC Beirne School of Law \\ Jacqueline Birt \\ UWA Business School, \\ University of Western Australia
}

\section{Abstract}

IS enables organizations to improve their productivity, streamline their business processes, and better understand the challenges and opportunities facing their business. These benefits can further accrue to individuals and organizations when they adopt and use the systems. While the benefits of IS are multifarious, IS adoption remains challenging. The far-reaching consequences of IS motivate research examining the antecedents of successful IS adoption both at individual and organizational levels. To examine the complexity of IS adoption, we undertook an interpretive case study of SBR adoption in Australia. We contend that SBR's context in Australia offers distinctive perspectives on the complexity of IS adoption. We found that IS adoption decisions can be based on both constructivist and ecological rationalities. Our findings can provide insight in improving understanding of the benefits of SBR and have implications for companies, regulators, standard setters, and the accounting profession, more generally.

\section{Introduction}

IS enables organizations to improve their productivity, streamline their business processes, and better understand the challenges and opportunities for their businesses. These benefits can further accrue to individuals and organizations when they adopt and use the systems (Hirschheim, 2007). While the benefits of IS are multifarious, IS adoption remains challenging. The challenges emerging from managing the factors effecting IS adoption are non-trivial.

At the organizational level, the factors contributing to IS adoption can be explained from two perspectives: rational assessments (i.e., economic rationality) (Fichman, 2004) and institutionalism (Teo, Wei, \& Benbasat, 2003; Mignerat \& Rivard, 2009; Nielsen, Mathiassen \& Newell, 2014). While both perspectives have been canvassed in the IS adoption literature, when explaining IS adoption at the organizational level potential gaps remain. In particular, 
prior research largely applies institutionalism in the context of structural isomorphism (i.e., mimetic, normative, and coercive). Two intriguing questions remain. First, why does structural isomorphism fail to fully explain organizational adoption decisions even though structural isomorphism exists (Compagni, Mele, \& Ravasi, 2015; Troshani, Parker \& Lymer, 2015)? Second, why do rational assessments also fail to fully explain organizational adoption decisions even though the adoption decisions are economically beneficial (Kaganer, Pawlowski \& Wiley-Patton, 2010; Swanson \& Ramiller, 1997)?

Early adopters primarily rationalize their decisions based on the rational assessments, for example the technical, cost, and benefit assessments of the technology (Fichman, 2004). This rationality, however, does not sufficiently explain adoption decisions because decisions may not be completely deterministic. Structural isomorphism often complicates rationality at the organizational level, that is, the prevailing complex institutional and social influences (Thornton, Ocasio, \& Lounsbury, 2012). Structural isomorphism has emerged as a complement to the rational assessments perspective. Structural isomorphism itself, however, is problematic because it focuses on macro analysis at the organizational level, and thus tends to overlook the roles and actions of individuals (Thornton et al. 2012; Compagni et al. 2015). We argue that organizations neither simply follow structural isomorphism nor rational assessments instead the two concepts are interacting. For example, organizational IS adoption may be affected by mimetic, normative or coercive isomorphism. At the individual level, however, individuals' behaviour (e.g., powerful actors and influencers) internally and externally influence organizations' decisions (Swanson \& Ramiller 1997). Individuals interactively connect and rationalize their day-to-day actions with organizations. Organizations may also pursue adaptive behaviour to satisfice themselves rather than seeking to maximize their utility.

Our work is motivated by seeking to address the deficiencies in explaining organizational rationality in IS adoption decisions. We use two conceptualizations of rationality to guide our study, namely, constructivist rationality and ecological rationality. Both conceptualizations originate in the economics domain (Smith, 2008). Constructivist rationality aligns with the notion of the economic rationalistic approach as the dominant paradigm in IS adoption (Fichman, 2004), while ecological rationality is largely similar with the concept of institutional logics (Nickerson \& Muehlen, 2006; Smith, 2008; Thornton et al. 2012). To examine the complexity of IS adoption, we undertook an interpretive case study of SBR adoption in Australia. The SBR context is relevant and provides scope for different conceptualizations, whereby, the context can neither be simply explained individually by structural isomorphism and/nor rational assessments perspectives. SBR should be evaluated holistically involving both constructivist rationality and ecological rationality. We contend that an investigation in the SBR context can complement findings from prior research and substantially increase our understanding of IS adoption. When compared to other information systems (IS) adoption cases with limited stakeholder influences, the complexity of SBR's context in Australia offers distinctive perspectives on the complexity of IS adoption.

SBR was introduced to reduce the costs associated with regulatory and business reporting via the use of eXtensible Business Reporting Language (XBRL)-enabled reporting systems. The involvement of multiple stakeholders such as government and regulatory bodies, accounting professional bodies, vendors, businesses, and information users, in concert with its multi-use context, contribute to the complexity of SBR adoption in Australia. Given the efficiencies SBR can and does offer, its adoption as the preferred means to submit businesses' financial reports 
appears to make good economic sense, why then has its uptake been so limited? Are Australian companies "radical non-adopters" or "rational non-adopters"?

The findings from this study yield theoretical and practical implications. First, we argue that IS adoption decisions can be based on both constructivist rationality and ecological rationality. Second, by considering both rationalities, we hope to shed light on factors that facilitate and hinder actual implementation of IS. Third, relevant to our study context, the findings provide timely feedback to regulators, preparers, and users of financial reports on reasons why widespread adoption of financial reporting via SBR has not occurred in Australia despite claims of much improved regulatory reporting efficiency (Nagy, Jubb, Rouse \& Cybulski, 2008; Azam \& Taylor, 2011; 2016). Fourth, the findings also provide some thoughts on improving understanding of the benefits of SBR adoption and, hence, its adoption rates. Fifth, the findings from this study have implications for companies, regulators, standard setters, and the accounting profession, more generally.

This paper proceeds as follows. Section 2 explains the conceptual background which includes a review of extant research relevant to IS adoption. Section 3 contains our research context, data, and research method. Section 4 presents our research findings. Section 5 discusses our research findings. Section 6 presents our research contributions and limitations. Section 7 concludes the study.

\section{Background}

\subsection{Two Dominant Paradigms in Information Systems Adoption - Economic Rationalistic and Institutionalism}

Responding to the challenges of IS adoption, IS research has examined the relevant antecedents of IS adoption and its applications. Multiple theories and frameworks, many of which have been adapted from the psychology, sociology, economics, and management fields have been applied in IS research to better understand IS adoption and applications. Two dominant paradigms emerged in studying IS adoption and use, namely, economicrationalistic (Fichman, 2004) and institutionalism (Teo et al. 2003; Mignerat \& Rivard, 2009; Nielsen et al. 2014). The economic-rationalistic approach emerged from Fichman's (2004) explanation of the dominant paradigm in IS adoption, whereas institutionalism evolved from the sociology field.

Economic-rationality suggests that the greater the resources organizations have, the greater the quantity of innovation they should generate (Fichman, 2004). The underlying assumption of this paradigm is the amount of organizational resources is linearly correlated to the economic returns. When explaining IS adoption, however, this assumption overlooks the complex multiple internal and external interactions to which organizations are subjected. This simplification necessitates research in IS adoption that considers the complexities beyond the rational model (Fichman, 2004).

The institutionalism approach to explaining IS adoption has gained support; particularly in light of the economic-rationalistic approach's limited ability to explain the complexity of IS adoption decisions. As North (1990, p.4), notes "In the jargon of the economist, institutions define and limit the set of choices of individuals". In other words, institutionalism takes into account the rules, constraints, and the context and circumstances in which individuals and organizations operate. While IS research has given this approach various terminologies (e.g., 
institutional forces, organizing vision, and innovating mindfulness), its roots remain in institutionalism (Nickerson \& Muehlen, 2006). The application of the institutionalism approach can generally be divided into macro and micro analyses. The macro analysis focuses on the organizations while the micro analysis suggests that individuals play important roles in businesses.

The macro analysis largely uses DiMaggio \& Powell's (1983) conceptualization of three forces, namely, mimetic, normative and coercive. In the context of IT adoption, the three forces can be explained as follows. Mimetic isomorphism occurs when organizations imitate other organizational IT adoption behaviours believing that such adoption could bring benefits. Normative isomorphism refers to the pressures on organizations from institutions or customers arising from technological advancements, whereas, coercive isomorphism compels organizations to adopt technology as a result of governmental regulations (Teo et al. 2003). Critics question this conceptualization as it overlooks agentive behaviour, i.e., individuals' actions that influence organizational behaviour. Further, the robustness of the conceptualization of the three forces remains questionable (Mignerat \& Rivard, 2009) as competitive and adaptive pressures may also necessitate businesses to adopt IS (Mignerat \& Rivard, 2009). In contrast, the micro analysis in the institutionalism approach suggests individuals, both as internal and external agents, have reciprocal relationships with the businesses. For example, the role of influential actors within particular businesses likely affects IS adoption decisions or community discourses toward particular IS features.

Thornton et al. (2012) conceptualized the macro and micro analyses in the institutionalism approach via institutional logics. Institutional logics take into account the interrelationships between individuals and organizations and permits the institutionalism approach to consider, not just social actions, but also organizational ecology. For example, some phenomena might be better explained by businesses adapting to local environments rather than global settings in their quest to attain business stability (Thornton et al. 2012). Institutional logics, therefore, have advanced the institutionalism approach making it more encompassing.

\subsection{Rationalities in Economics - Constructivist Rationality and Ecological Rationality}

Constructivism, as described by Smith (2003, p.468) "uses reason to deliberately create rules of action, and create human socioeconomic outcomes deemed preferable, given particular circumstances, to those produced by alternative arrangements." That is, constructivist rationality seeks to arrive at optimum outcomes, rather than outcomes that satisfice, by relying on decision making that is deliberative, exercises cognitive processes, expectancies, and economic considerations.

Unlike constructivist rationality, ecological rationality contends that individual and organizational (business) decision making is not always deterministic, deliberative, and utility maximizing. Ecological rationality further contends that the context in which individuals and organizations interact, and operate in, can influence their decision-making often compelling them to satisfice themselves and survive within their environment (Smith, 2008; Levin \& Aharon, 2014). In deference to ecological rationality, Smith (p.468) then goes on to note, “..., it is important to remain sensitive to the fact that human institutions and most decision making is not guided primarily, if at all, by constructivism." 


\subsection{Two Dominant Paradigms versus Rationalities in Economics}

While both sets of explanations of IS adoption arose from different fields, the economic-based IS adoption paradigm conceptualizes IS adoption like that of institutionalism, that is, via constructivist rationality and ecological rationality (Smith, 2008). A similarity also exists between the economic-rationalistic approach and constructivist rationality (constructivism) in the economics (Smith, 2008). Thus, the two dominant paradigms in IS adoption decisions, namely, the economic rationalistic approach and the institutionalism approach display similarities to the two economics-based rationalities. The economic rationalistic and constructivist rationality approaches have their roots in rational actions and economic considerations, while the institutionalism approach and ecological rationality have the similar core ideas, namely, institutional influences and adaptiveness relative to the surrounding environment. Figure 1 presents the schema of the two dominant paradigms in IS adoption decisions and illustrates their alignment with constructivist and ecological rationalities.

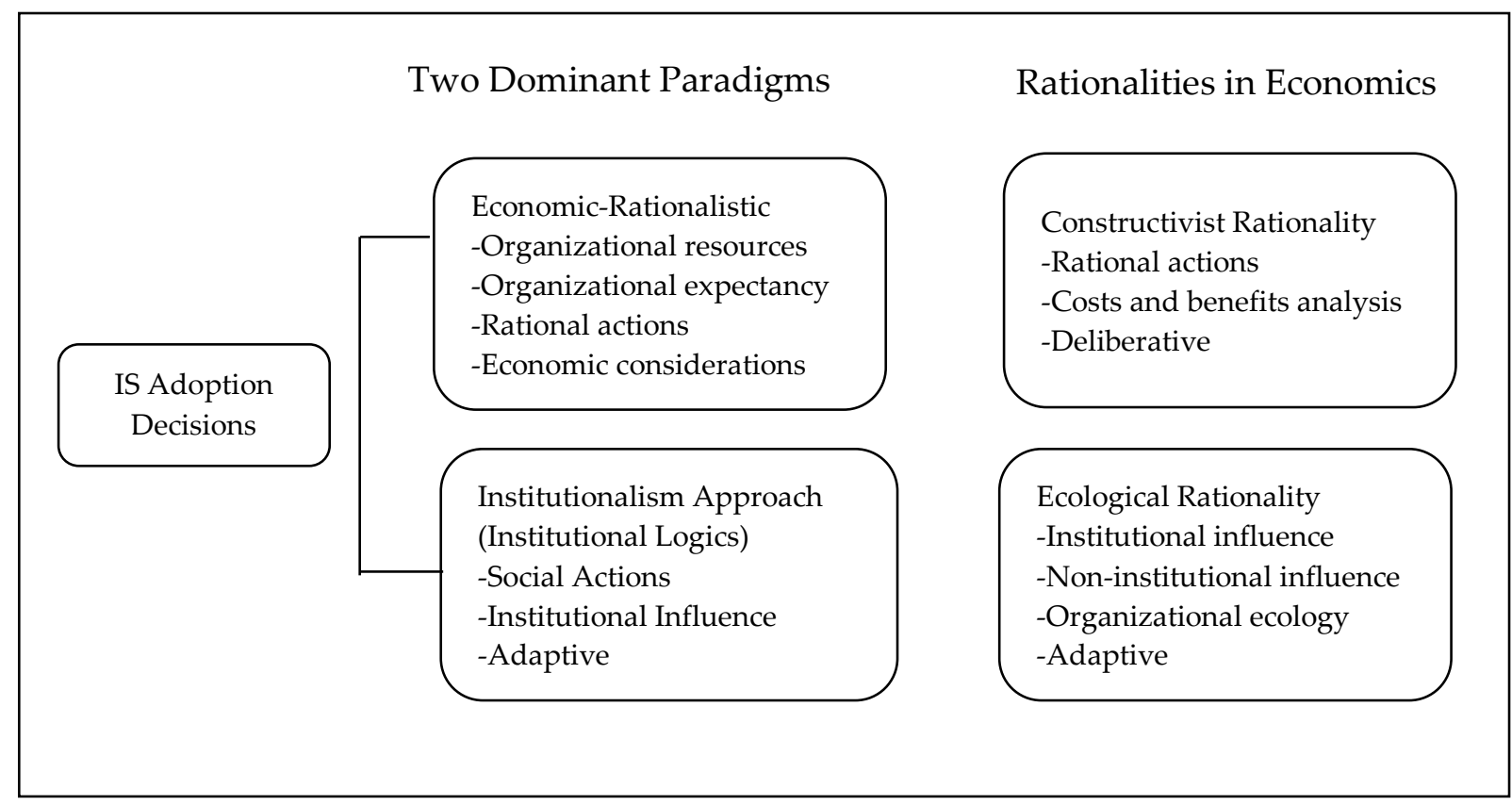

Figure 1. Two Dominant Paradigms in IS Adoption

Both institutional logics and ecological rationality ostensibly have similar underlying assumptions, whereby collective individuals' actions shape institutions and vice versa. Overall, institutions are subject to institutional and environmental forces (Nickerson \& Muehlen, 2006; Smith, 2008; Thornton et al. 2012). Smith notes that his idea of ecological rationality is concerned with institutional adaptations with their surrounding environment such as markets, management, social, and other informal and formal systems. While institutional influence occurs via institutions following institutionalization processes (e.g., regulatory policies, social structures, technologies (Mignerat \& Rivard, 2009), ecological rationality appears to consider both institutional and non-institutional influences.

To make our conceptualization of rationalities comparable, we use the term ecological and constructivist rationality to guide our study. Both rationalities align with the two dominant paradigms in IS adoption. We submit that the use of two economics-based rationalities better articulates IS adoption than the use of the current dominant IS adoption paradigms. By 
considering both constructivist and ecological rationalities, we hope to add an environmental context to our investigation and uncover factors that facilitate or hinder actual implementation of SBR in businesses.

\subsection{Constructivist Rationality, Ecological Rationality, Organizational Affordance, and Organizational Use of IS}

Relevant to IS adoption, constructivist rationality can be defined as the deliberate use of reason to analyse IS adoption and use based on the expectancy alternatives (Smith, 2008). Following this definition, we argue that when making IS adoption decisions, individuals will evaluate the costs and benefits of the technology, as well as whether their organizations are willing to spend resources on the adoption process. In IS literature, the aforementioned statement corresponds with performance and effort expectancy (Venkatesh et al. 2003). While the two constructs were originally used at the individual level, at the organizational level, performance and effort expectancy are relevant in relation to the expectations of groups of people interacting with each other. In this study we defined performance expectancy as the organizational consideration given to whether or not IS will enable and afford organizations to pursue their goals and obtain benefits (e.g., economic or financial) from IS use. We define effort expectancy as the degree to which organizations are ready to use IS in light of their resources.

Aside from considering the costs and benefits of adopting new technology, organizations are interested in what they can do with technology and how such technology can transform their business (Markus \& Silver, 2008). This consideration depends on the features (i.e., functionality, ability, and quality) that the technology can offer to organizations. In this case, the scope of technology characteristics can include single systems and/or multiple systems. We argue that technological characteristics, therefore, contribute to IS adoption decisions and how such technology is implemented in organization.

To compliment the use of constructivist rationality, organizations may also use ecological rationality to adapt to their immediate environment such as supporting conditions, institutional influence, and organizational context. Ecological rationality has its roots in ecological psychology suggesting that the surrounding environment (i.e., supporting environment, institutional influence, organizational context) in which people live, and interact with, plays a significant role in influencing the way they behave. This environment (e.g., objects, places, events, and circumstances) can help afford people to behave in a certain way. Arising from this notion, the concept of affordance emerged in IS literature. Volkoff \& Strong (2013, p. 823), for example, define affordance as "the potential for behaviours associated with achieving an immediate concrete outcome and arising from the relation between an object (e.g., an IT artefact) and a goal-oriented actor or actors". At the organizational level, Zammuto, Griffith, Majchrzak, Dougherty \& Faraj (2007) specifically use the term affordance to capture the interrelationships between technology and business features that can conceivably affect businesses' actions. Multiple affordance concepts appear in the literature, for example, functional affordance (Markus \& Silver, 2008) and organizational affordance (Zammuto et al. 2007).

Taken together, we incorporate organizational affordance in our model to explain the possible behaviours arising from interactions between businesses and technology to afford their goals. This explanation aligns with Zammuto's et al. (2007) definition of organizational affordance reflecting the potential for businesses to coordinate actions to pursue their intended goal(s). 
More specifically, organizational affordance emerges from the perceptions and actions of individuals within the business towards particular technologies and how those particular technologies should actually be used. While organizational affordance is a useful concept to help explain IS adoption and use, few studies offer insight into the antecedents of organizational affordance. Zammuto et al., (2007), for example, suggest that social settings such as, expertise, business processes and procedures, boundary-spanning approaches, and social capacities can determine organizational affordance (Majchrzak \& Markus, 2012; Seidel, Recker \& vom Brocke, 2013; Stendal, Thapa \& Lanamäki, 2016; Chatterjee, Moody, Lowry, Chakraborty \& Hardin, 2015)

To illustrate, businesses with high IT experience would have different strategic implementations of enterprise resource planning (ERP) software than businesses with little IT experience (Zammuto et al. 2007). While the features of the ERP remain similar, the way businesses view and interact with the ERP could lead to different strategic implementations. While the concept of affordance was originally derived from ecological psychology implying that affordance aligns with ecological rationality (Markus \& Silver, 2008), the aforementioned examples also support the alignment of affordance with constructivist rationality (Zammuto et al. 2007; Leonardi, 2007). We speculate that businesses may develop such constructivist rationality via their expectancies toward particular technologies. Alternatively, the characteristics of the technology per se can determine the way businesses should implement the technologies helping them to afford their goals. Following this argument, we posit that constructivist rationality, ecological rationality, technology characteristics, and organizational affordance all play a role in the context of organizational IS adoption and use decision.

Based on the two conceptualizations (i.e., constructivist rationality and ecological rationality) we proposed eight relevant constructs (i.e., performance expectancy, effort expectancy, technology characteristics, supporting environment, institutional influence, organizational context, organizational affordance, and organizational use of IS) that can be used to explain IS adoption decisions. Of the eight categories, two categories (i.e., performance expectancy and effort expectancy) are subcategories of constructivist rationality, and three categories (i.e., supporting environment, institutional influence, and organizational context) are subcategories of ecological rationality. Table 1 shows our proposed constructs.

\begin{tabular}{|c|c|c|c|c|}
\hline Constructs & $\begin{array}{l}\text { Definitions and } \\
\text { Explanations }\end{array}$ & Adapted from & $\begin{array}{c}\text { Similarities to the } \\
\text { ideas of prior } \\
\text { studies }\end{array}$ & $\begin{array}{c}\text { Difference } \\
\text { between the ideas } \\
\text { of prior studies }\end{array}$ \\
\hline $\begin{array}{l}\text { Constructivist } \\
\text { Rationality }\end{array}$ & $\begin{array}{l}\text { Defined as the } \\
\text { deliberate use of } \\
\text { reason to analyze IS } \\
\text { adoption and use } \\
\text { based on the } \\
\text { expectancy } \\
\text { alternatives. }\end{array}$ & Smith (2008) & $\begin{array}{l}\text { Similar in meaning } \\
\text { to the deliberate } \\
\text { use of reasons } \\
\text { when making } \\
\text { decisions. }\end{array}$ & $\begin{array}{l}\text { The concept of } \\
\text { constructivist } \\
\text { rationality in the } \\
\text { economic field is } \\
\text { broader than in the } \\
\text { current study. The } \\
\text { definition of } \\
\text { constructivist } \\
\text { rationality } \\
\text { proposed in this } \\
\text { study is specific to } \\
\text { organizational } \\
\text { behavior towards } \\
\text { IS adoption use. } \\
\text { The underlying }\end{array}$ \\
\hline
\end{tabular}




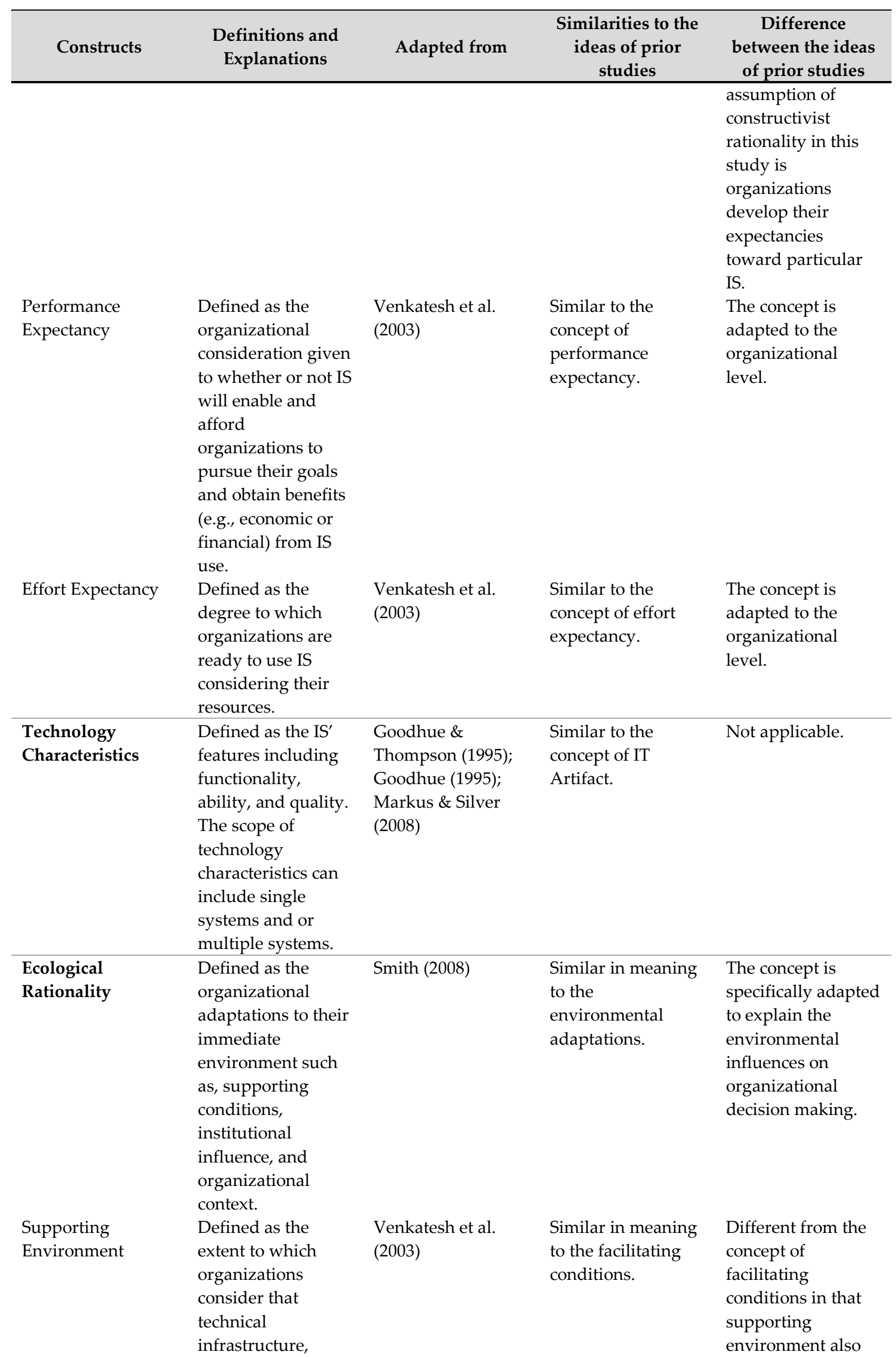




\begin{tabular}{|c|c|c|c|c|}
\hline Constructs & $\begin{array}{l}\text { Definitions and } \\
\text { Explanations }\end{array}$ & Adapted from & $\begin{array}{c}\text { Similarities to the } \\
\text { ideas of prior } \\
\text { studies }\end{array}$ & $\begin{array}{c}\text { Difference } \\
\text { between the ideas } \\
\text { of prior studies } \\
\end{array}$ \\
\hline & $\begin{array}{l}\text { market and } \\
\text { consumer demand } \\
\text { exists to support IS } \\
\text { adoption and use. }\end{array}$ & & & $\begin{array}{l}\text { considers } \\
\text { regulatory policies, } \\
\text { and market and } \\
\text { consumers' } \\
\text { demand. }\end{array}$ \\
\hline $\begin{array}{l}\text { Institutional } \\
\text { Influence }\end{array}$ & $\begin{array}{l}\text { Defined as the } \\
\text { extent to which an } \\
\text { organization } \\
\text { considers that other } \\
\text { organizations and } \\
\text { policies can } \\
\text { influence their IS } \\
\text { adoption and use } \\
\text { decision. }\end{array}$ & $\begin{array}{l}\text { Venkatesh et al. } \\
\text { (2003) }\end{array}$ & $\begin{array}{l}\text { Similar in meaning } \\
\text { to the social } \\
\text { influence. }\end{array}$ & $\begin{array}{l}\text { Different from the } \\
\text { concept of social } \\
\text { influence in that the } \\
\text { influential factor is } \\
\text { organizations } \\
\text { rather than social } \\
\text { peers. We consider } \\
\text { supporting } \\
\text { environment, and } \\
\text { organizational } \\
\text { context differ from } \\
\text { institutional } \\
\text { influence in term of } \\
\text { the } \\
\text { institutionalizations } \\
\text { processes. (Tolbert } \\
\text { and Zucker, 1996; } \\
\text { Greenwood et al., } \\
\text { 2002) }\end{array}$ \\
\hline $\begin{array}{l}\text { Organizational } \\
\text { Context }\end{array}$ & $\begin{array}{l}\text { Defined as the } \\
\text { organizational size, } \\
\text { organizational type. }\end{array}$ & Not applicable & Not applicable. & Not applicable. \\
\hline $\begin{array}{l}\text { Organizational } \\
\text { Affordance }\end{array}$ & $\begin{array}{l}\text { Potential behaviors } \\
\text { arising from the } \\
\text { collective views of } \\
\text { individuals within } \\
\text { organizations when } \\
\text { interacting with } \\
\text { technology to } \\
\text { afford their goal } \\
\text { oriented actions. }\end{array}$ & $\begin{array}{l}\text { Markus \& Silver } \\
\text { (2008); Leonardi } \\
\text { (2011); Volkoff \& } \\
\text { Strong (2013) }\end{array}$ & $\begin{array}{l}\text { Similar in meaning } \\
\text { to affordance } \\
\text { concept. }\end{array}$ & Not applicable. \\
\hline $\begin{array}{l}\text { Organizational Use } \\
\text { of IS }\end{array}$ & The actual use of IS. & $\begin{array}{l}\text { Venkatesh et al. } \\
\text { (2003) }\end{array}$ & $\begin{array}{l}\text { Similar in meaning } \\
\text { to use behavior }\end{array}$ & $\begin{array}{l}\text { The concept is } \\
\text { adapted to the } \\
\text { organizational } \\
\text { level. }\end{array}$ \\
\hline
\end{tabular}

Table 1. Explanatory Constructs in IS Adoption Decisions

\section{Research Context, Data and Research Method}

\subsection{Research Context: SBR Adoption in Australia}

SBR is a standard approach to online or digital record-keeping, and extensible business reporting language (XBRL) is the enabling technology for SBR for business transactions. The use of XBRL is expanding globally. In the US, the Securities and Exchange Commission (SEC hereafter) allowed companies to voluntarily file XBRL-based company reports starting 2005 and in 2009 mandating XBRL-based reporting for public companies (US Securities and 
Exchange Commission, 2016). Countries that have adopted XBRL for business-to-government reporting include Canada, UK, Singapore, Spain, and Sweden (Azam \& Taylor, 2011; Chen, 2012). Countries which have mandated XBRL for reporting to government agencies include Japan, Denmark, The Netherlands, and the United Kingdom.

In Australia, SBR was introduced in 2010 to reduce the regulatory reporting burden, and in consequence, also reduce the cost burden on businesses. One of the main benefits of SBR is its ability to create significant efficiencies in the regulatory reporting process (Robb, Rohde \& Green, 2016). In the context of business reporting, the costs arise due to the exchanges between those who prepare (data and report producers) and those who use (data and report consumers) financial reports. As noted in its SBR options paper, the premise of SBR is that businesses' reporting information to Government will be 'recorded once, reported to many' to help enhance business efficiency (Treasury, 2012). Despite SBR's availability since 2010, its awareness and adoption has been limited in Australia (Nagy et al. 2008, Azam \& Taylor, 2011; 2016). To help encourage uptake of SBR, since 2015 the Australian Securities and Investments Commission (ASIC) has permitted the use of improved digital reporting technology (iXBRL) removing the requirement for lodging entities to submit their financial reports as human readable PDFs (previously businesses using XBRL also had to submit human readable PDFs).

Reported benefits of using XBRL include improving the efficiency of financial reporting, accuracy of the financial data, timeliness and reliability of the data, and the ease with which data can be acquired and analysed (Garner, Henderson, Sheetz, \& Trinkle, 2013). In Australia, the purported benefits of using SBR include; the adoption of a common reporting standard (XBRL taxonomy), making financial reporting a by-product of natural business processes, and providing an electronic interface to agencies directly from accounting software to provide validation of reports (Treasury 2012).

Prior research in the XBRL literature has primarily focused on the theoretical attributes and benefits associated with XBRL-based reporting from a user perspective (Alles \& Piechocki, 2012; Baldwin, Brown \& Trinkle, 2006; Janvrin \& Mascha, 2010; Vasarhelyi, Chan \& Krahel, 2012; Muthusamy, Bir \& Birt, 2017). Recent research has found that the anticipated benefits of XBRL focus predominantly on efficiency within the realm of the data and report-producers and on effectiveness within the realm of the data and report-consumers (Robb, et al. 2016). Financial statements using XBRL, arguably, assist in increasing information transparency and ease of acquisition for financial analysis tasks (Muthusamy et al. 2017; Janvrin, Pinsker, \& Mascha, 2013; Steenkamp \& Nel, 2012). Transparency of financial information is also claimed to be enhanced with the use of XBRL. Transparency refers to the ability to identify and evaluate financial information in all parts of financial reports, including information contained in the disclosure notes (Hodge, Kennedy \& Maines, 2004). XBRL's tagged information is clear and well documented and allows users to integrate information from various locations in the financial reports (Muthusamy et al. 2017; Hodge et al. 2004; Alles \& Piechocki, 2012). Further, XBRL allows information to be retrieved on a timely basis (Azam \& Taylor, 2011). These features, particularly, the tagging permitted by XBRL-enabled reporting are absent in traditional financial reporting.

While studies report the numerous advantages associated with the perceptions of users and the ease of preparation of reports, globally, voluntary XBRL adoption has been limited. Possibly, this limited adoption is due to stakeholders' concerns, e.g., filers, standard setters, regulators and/or software companies who have yet to promote the potential of SBR in terms 
of data reliability, value-adding, and easily integrated consumption tools. There are other issues concerning the current "language" firms' management information systems use and the on-going commitment of regulators (Harris \& Morsfield, 2012). Other matters associated with low adoption rates include, but are not limited to, perceptions of the low business value of XBRL for internal use, lack of education in the business community of the benefits of XBRL, and a lack of pressure to adopt XBRL from regulators (Garner et al. 2013).

Globally XBRL-enabled reporting is gaining speed. For example, the European Banking Authority is mandating XBRL-enabled CO-REP/FIN-REP for regulatory reporting from the EU member states (European Banking Authority, 2013). The US SEC now has mandatory XBRL-enabled financial reporting for all listed companies. Increasingly, it appears that if Australia wants to be part of the global capital market, it may find itself having to ensure much greater take-up of SBR - which is currently voluntary. Australia is not unique in having limited SBR uptake (e.g., Swedish Bolagsverket), but somewhat unique in that during November 2012 Treasury released an Options Paper calling for submissions on the use of SBR for financial reports. Except for one confidential submission, all submissions to Treasury have been made public.

This paper examines stakeholder submissions offered in response to the three proposed SBR Reporting Options canvassed in Treasury's 2012 Options Paper. The first option suggested by Treasury is the mandatory lodgement of financial reports using SBR. The second option is the voluntary lodgement of financial reports in iXBRL format, and the third option is to retain the status quo, i.e., mandatory PDF/paper reporting and voluntary XBRL.

\subsection{Data}

During the period November 2012 to March 2013, Treasury sought stakeholders' opinions on how SBR can be leveraged to enhance business reporting efficiency. Treasury received 24 submissions from multiple stakeholders. To undertake cluster analysis as to whether Australian SBR adoption matches with the two conceptualizations of rationality, we used the 23 publicly available SBR submissions to (Australian) Treasury and classified them into seven groups: regulator; professional body; company; accounting firm; developer; interest group; and a professional body's Australian Business School representative. Table 2 presents a summary of the submissions and stakeholder group.

\begin{tabular}{|c|c|c|}
\hline No. & Submissions & Stakeholder group \\
\hline 1 & Ernst \& Young & Accounting firm \\
\hline 2 & Grant Thornton & Accounting firm \\
\hline 3 & Pitcher Partners & Accounting firm \\
\hline 4 & PricewaterhouseCoopers & Accounting firm \\
\hline 5 & Westworth Kemp Consultants & Accounting firm \\
\hline 6 & Australian Business School Academic Submission/CPAA & $\begin{array}{l}\text { Academic } \\
\text { Representative }\end{array}$ \\
\hline 7 & Arkk Solutions & Company \\
\hline 8 & BHP Billiton & Company \\
\hline 9 & CaseWare & Developer \\
\hline
\end{tabular}




\begin{tabular}{lll}
\hline No. & \multicolumn{1}{c}{ Submissions } & \multicolumn{1}{c}{ Stakeholder group } \\
\hline 10 & IMPACT Management Group & Developer \\
11 & Muli Management & Developer \\
12 & VillageMall Operations & Developer \\
13 & The Group of 100 & Interest group \\
14 & XBRL UK & Interest group \\
15 & Australian Bankers' Associations, Inc. (ABA) & Professional body \\
16 & Australian Institute of Superannuation Trustees (AIST) & Professional body \\
17 & Australian Mutual Provident (AMP) & Professional body \\
18 & Australian Shareholders' Association (ASA) & Professional body \\
19 & Business Council of Australia (BCA) & Professional body \\
20 & CPA Australia and the Institute of Chartered Accountants in Australia/CPA & Professional body \\
20 & ICAA (now Chartered Accountants Australia and New Zealand/CAANZ) & Professional body \\
21 & Institute of Certified Bookkeepers & Professional body \\
22 & Australian Accounting Standard Board (AASB) & Regulator \\
\hline
\end{tabular}

Table 2. Submissions to (Australian) Treasury relative to options for SBR adoption

\subsection{Research Method}

This study uses an interpretive case study approach (Klein \& Myers, 1999). We expect to provide theoretical insight derived from our case study (Eisenhardt, 1989). We used cluster analysis as our analytical approach and synthesizing strategy of our interpretive case study (Mills, Durepos \& Wiebe, 2010). In this study, we have no predefined independent and dependent variables. We, however, use the two conceptualizations of rationality as a sensitizing device to guide us to derive a priori constructs of the coding scheme. This schema is necessary to make sense of the textual data and to guide us to examine the themes embedded within the SBR submission documents. Table 3 presents our coding scheme.

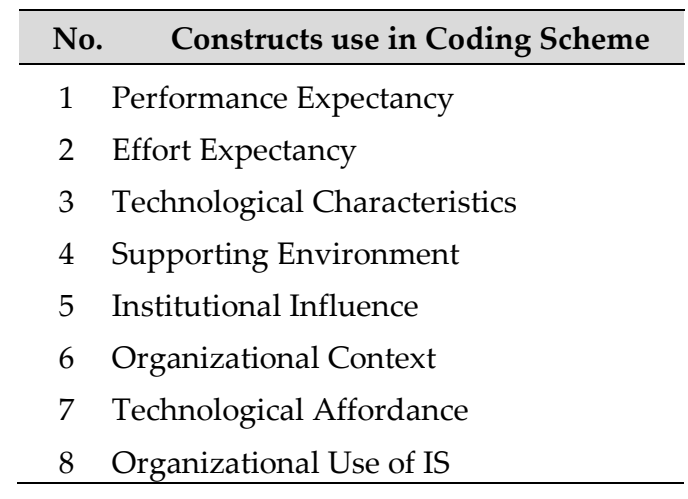

Table 3. Coding Scheme

Three authors were involved in the cluster analysis by manually coding the submission documents. Each author analysed all 23 submission documents, evaluated the same contents 
and coded sentences from the documents into the relevant proposed constructs. We then counted how many times each constructs appeared across the 23 documents. For the purpose of inter-rater reliability analysis, we avoided double counting for each category; therefore, the maximum numbers of variables appearing in the overall documents are 23 . We employed interclass correlation (ICC) to analyse the inter-rater reliability (Shrout \& Fleish, 1979; McGraw \& Wong, 1996). The interrater reliability analysis (ICC=.817) shows strong agreement with the coding analysis. To store the data and to facilitate further analyses of the documents we corroborated the coded documents using NVivo.

\section{Case Study Findings}

We undertook cluster analysis of the 23 submission documents based on coding similarity to give us some indication of the proximity between categories. The result of the cluster analysis shows close proximity between constructivist and ecological rationalities (see Figure 2). We contend that this proximity implies that these two rationalities form the basis of analysing IS adoption decisions. Along with technological characteristics, these two rationalities are subordinate to the branch of organizational affordance. This finding is logically consistent with prior literature whereby collective rationalities among individuals within organizations facilitate rationalities to act on affordances with the technologies (Zammuto et al. 2007; Leonardi, 2011; Volkoff \& Strong, 2013). To deepen our cluster analysis, we examine relevant coded sentences or paragraphs from the 23 submission documents associated with constructivist and ecological rationalities, technological characteristics, organizational affordance, and organizational use of information systems.

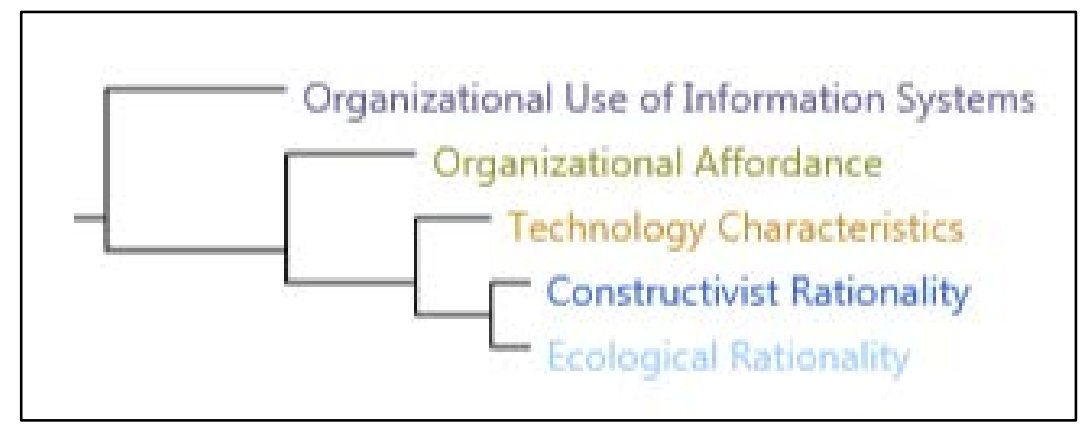

Figure 2. Cluster analysis based on coding similarity

\subsection{Constructivist Rationality and Ecological Rationality}

Recall, in our coding schemes, two categories, i.e., performance expectancy and effort expectancy embody constructivist rationality. In our definition, performance expectancy reflects organizational beliefs relative to the benefits of IS adoption, whereas effort expectancy reflects organizational beliefs relative to the availability of the necessary resources to adopt IS. As was anticipated these two expectancies appear in the documents.

CPA Australia and the Institute are strong supporters of government programs that improve the efficiency and productivity of the Australian economy. We believe that the option of the inline eXtensible Business Reporting Language (iXBRL) for the lodgement of financial reports via Standard Business Reporting (SBR) has the capacity to make a positive difference to the Australian economy (CPA ICCA) 
PwC supports initiatives that improve the transparency of financial reporting, the comparability of information in the global capital markets, and efficiencies in the systems and processes used by businesses. We believe the SBR initiative will provide significant benefits across all of these areas (PwC).

ABA members welcome initiatives to reduce the regulatory burden on business, but believe that mandatory lodgement at this time would require extensive and costly changes for all reporting systems, for all businesses, when other regulatory requirements are also driving major technology projects (ABA).

The cost to preparers was high and incremental as they often had to upgrade their financial reporting software to acquire a financial reporting tool with auto tagged templates and employ additional qualified staff to create tagged templates and complete the preparation of the tagged financial statements (BHP Billiton).

Stakeholders were obviously aware of the potential consequences of SBR adoption including increased productivity and efficiency. At the same time, they were concerned with the costs and additional resources required to facilitate SBR adoption. These considerations reflect deliberate rationality involving costs and resources availability to pursue greater benefits from SBR adoption. This finding helps confirm our expectation that performance expectancy and effort expectancy are relevant proxies for constructivist rationality.

In contrast to constructivist rationality where decision-making is deliberative, decisionmaking based on ecological rationality is adaptive. Ecological rationality takes into consideration the environmental conditions under which decisions are made. Organizations are inextricably linked with individuals, community, and their environment compelling them to be more adaptive and to create social constructions in which they produce and reproduce meanings, and rationalize their decisions (Smith, 2008; Thornton et al. 2012). We found stakeholders were concerned about the supporting environment (e.g., availability of technical infrastructure, market and consumer demand) as presented in the following excerpts.

CSA considers that mandatory implementation - through the push for consistent information from government agencies - will need to overcome several fundamental framework issues before SBR will be readily adopted by business. As noted above, the government must first communicate with business about SBR and how it interacts with other reporting frameworks, and also articulate the benefits of SBR to business. Without such clarity as to the benefits, any attempt to mandate SBR is likely to be illreceived (CSA).

One of the most commonly quoted reasons for the slow take-up of SBR was the lack of a comprehensive accounting software available on the market and the fact that the key players (e.g., MYOB) had not released an SBR-enabled product at that point (Australian Business School Academic Submission/CPAA).

We also found institutional influence. One such example occurs when government and their regulatory policy necessitate organizations to rationalize their SBR adoption decisions.

Without regulatory encouragement of SBR lodgement it is difficult to entice businesses to change their processes and means of lodging statutory reports such as the ASIC financial statements (IMPACT Management Group). 
If the real drivers for the use of SBR are the efficient operation of government bodies, the only way to achieve adoption at present will be through compulsion. That compulsion needs to be aligned with the creation of software accessible and affordable to the range of businesses that will be affected by SBR based lodgement (Westworth Kemp).

Aside from supporting environment and institutional influence, business context such as, businesses' size and type were also considered when making SBR adoption decisions.

We believe that a difference of 12 months is sufficient difference in mandatory adoption dates between larger and smaller businesses will be appropriate, based on the dates that will be used to implement the SuperStream reforms (AIST).

Yes, we do believe there is justification for excluding certain entities from a mandatory requirement to lodge financial reports via SBR, should that proposal proceed. Given there is limited interest and a small number of stakeholders in non-listed companies, we believe that the SBR requirement should be limited to listed public entities (BHP Billiton).

Despite the clear distinction between constructivist and ecological rationalities, our cluster analysis also found common ground between them. The following texts show that government support and engagement with companies potentially increases their awareness of the costs and benefits of SBR adoption.

A more comprehensive engagement strategy with corporate Australia that is focused on understanding the costs and benefits of businesses adopting SBR to lodge their financial reports. Although we acknowledge the Government has already undertaken a consultation process with the business community on its proposals, we would encourage a more far reaching, comprehensive engagement strategy that aims to educate businesses on the potential benefits and costs of implementing SBR (PwC).

Supporting environment reflects the environmental influence, whereby businesses consider whether sufficient technical infrastructure, market, and consumer demand exists to support IS adoption and use. Similar to the supporting environment, institutional influences, such as organizations, government, and their regulatory policy influences constructivist rationality.

Use of SBR hitherto has been voluntary and the rate of adoption has been low. Without some sort of incentive and compulsion, the take-up rate is likely to continue to be low and the potential benefits are unlikely to eventuate (Westworth Kemp).

Different types of businesses also apply organizational rationality towards the costs and benefits of SBR adoption. For example, the size of businesses determines the extent to which they consider their resources are sufficient to pursue the benefits of SBR adoption.

We note that with any new mandated format, there are normally costs incurred in changing over. These costs are going to be proportionately larger for small businesses as opposed to larger businesses, and we propose that there be a sufficiently large transition period, in order to allow for small business to spread the costs of implementation over, where necessary (AIST). 


\subsection{Technological Characteristics}

Businesses' decisions to adopt IS are more complex than that of individuals' decisions. More specifically, SBR's features and capabilities are among the key themes in the submission documents as noted in the following text.

We consider $\mathrm{XXBRL}$ to be more suitable than XBRL given that $\mathrm{XXBRL}$ enables rendering financial data in a more visually appealing format for people. XBRL was originally designed as a machine-to-machine language (Ernst \& Young).

The electronic interface has the ability to validate the reporting information and confirm that reports have been received by the relevant government agency (Australian Business School Academic Submission/CPAA).

When contributors to the White Paper expressed their opinions relative to SBR features and specifications, the context is intertwined with both constructivist and ecological rationalities. For example, the capabilities of SBR to deliver human and machine-readable information are associated with stakeholders' performance expectancy. Similarly, stakeholder awareness of SBR's features should accord with the stakeholders' environment. The following texts illustrate such relationships.

The options paper notes an important benefit of financial reports lodged using iXBRL are their design for use by both machines and humans (CPA ICAA ${ }^{1}$ ).

Allowing five years will enable listed entities to include SBR in any planned software upgrades that currently exist, rather than it having to be done as a completely separate compliance exercise (CPA ICAA).

It also needs to undertake a communication program that assists business to understand SBR, how it interacts with existing reporting frameworks and processes, and how business as well as government agencies will benefit from its implementation (CSA).

\subsection{Organizational Affordance and Organizational Use of Information Systems}

The SBR/XBRL adoption decision is challenging due to cost and benefit considerations and environmental factors. Such considerations and factors include performance and effort expectancy, technological characteristics, and regulatory support, all of which critically determine the likelihood of XBRL adoption and use (Dunne, Helliar \& Lymer 2013; Guilloux, Locke, \& Lowe 2013; Valentinetti \& Rea 2013). These considerations and factors can have multiple interdependencies and interactions, for example, the cost and effort of implementing XBRL into existing reporting systems may not make XBRL implementation straightforward. Additionally, regulatory policy (mandatory vs. voluntary) can have different impacts on XBRL implementation:

It is true that the first year can involve some additional effort on the part of finance teams and filers, but our experience is that for most clients the second year of iXBRL is far less painful than they had been led to expect, with widespread acceptance as filers have established their own XBRL routines (Arkk Solutions).

\footnotetext{
${ }^{1}$ Now CAANZ (Chartered Accountants of Australia and New Zealand).
} 
A rush to mandate it could generate a negative perception of SBR as another prescriptive government reporting requirement. In the short-term this could lead to the outsourcing of report preparation, which would undermine the fundamental objectives and potential benefits of the SBR program (BCA).

This raises the issue as to whether the IFRS Taxonomy has sufficient tags/elements. Fewer amounts of tags would mean that entities will need to create their own specialized dictionary or extension taxonomy, which increases costs and decreases comparability of financial information between entities of the same industry (Ernst \& Young).

The current SBR capability uses XBRL and the documents produced by XBRL are not presented in an easily understandable format, hence they are generally only machinereadable. Therefore, this means that if XBRL is used it would be necessary to continue with mandatory lodgement of financial reports in either paper or PDF form (AMP).

Financial reports, which are already prepared under the regime of comprehensive international financial reporting standards, contain qualitative as well as quantitative data. SBR's focus on quantitative data could detract from the usefulness of these reports to users (AMP).

We also found a relationship between organizational affordance and organizational use of IS, as shown in the following text.

It should be noted, however, based on the feedback provided by the practitioners that they tended to use SBR to simply lodge reports rather than collate data and create reports directly from their accounting software. The feedback indicated that the level of understanding of SBR among reporting practitioners was still rather limited and they did not take the benefit of all of the functionalities and features of SBR. (Australian Business School Academic Submission for CPAA).

Relative to the organizational use of IS, the following texts attest to the limited SBR uptake in Australia.

Of those respondents who were aware of SBR to a greater or lesser extent (in total around 58 per cent), only 15 per cent had used SBR to lodge their business reports to the government (Australian Business School Academic Submission for CPAA).

The take-up of SBR among businesses and reporting practitioners has been significantly lower than anticipated by the SBR stakeholders. The initial business case developed by the Treasury in 2008 predicted a take-up rate of 12 per cent in the year (Australian Business School Academic Submission/CPAA).

\section{Discussion}

Our case study findings reveal themes embedded in the 23 publicly available submissions to the Treasury. Following the coding scheme, we find that the SBR adoption in Australia reflects our a priori categories of the coding scheme (see, Research Method section). Not only do the submissions reflect expectations, but they also adhere to the relationships between categories in our coding scheme. In effect, the context in which the stakeholders ${ }^{2}$ expressed their opinions

\footnotetext{
2 Sentiments and views towards SBR adoption by stakeholder type are summarized in Appendix A.
} 
toward SBR adoption helped guide us to the appropriate categories in our coding scheme, as well as to their related categories in the scheme. In the following, we begin the discussion from the constructivist and ecological rationalities' perspectives, then we describe the relationships between the two rationalities and their impact on SBR's uptake.

Our study suggests that both performance and effort expectancy are the two essential bases for constructivist rationality. That is, businesses' consideration of the costs and benefits reflect their constructivist rationality in any SBR adoption decisions. Businesses are able to develop their constructivist rationality via available XBRL information, e.g., from government agencies, software vendors, and consulting firms. We found that stakeholders are aware that they have to have sufficient financial, technical, and human resource wherewithal to adopt SBR. Stakeholders were also quite aware that SBR is capable of improving government efficiency and productivity, but did not seem to place any particular significance on this capability.

Constructivist rationality in SBR adoption is of little surprise, mirroring similar adoptions in other jurisdictions. For example, the rationale behind the voluntary filing programs in the US was to investigate the costs and benefits of XBRL use (Debreceny et al. 2005). Similarly, in the UK, XBRL adoption was initially introduced to reduce costs associated with regulatory compliance (Troshani et al. 2015). Because XBRL or SBR adoption requires involvement of multiple stakeholders and multifaceted interactions, constructivist rationality is not a sufficient explanation for SBR adoption. While the costs and effort are necessarily assessed for SBR adoption, the benefits of XBRL may not directly accrue to every organization, rather, the greater benefit may accrue to the entire economy as is the case of The Netherlands SBR (Chen, 2013).

Unlike constructivist rationality which refers to the deliberate use of reason to achieve the desired goals (Smith, 2008), we assume that ecological rationality is less deliberately pursued. Ecological rationality suggests that the immediate environment compels organizations to ecologically rationalize their decision making (Smith, 2008). Recall, in our study, ecological rationality is concerned with the supporting environment, institutional influence, and organizational size. In terms of supporting environment, stakeholders' concerns are related to SBR's alignment with the existing systems and existing reporting framework, as well as the availability of appropriate software to facilitate SBR. Aligning with Zammuto et al. (2007) and Volkoff \& Strong (2013), the potential for XBRL adoption by organizations is influenced by their ability to make sense of the interdependencies and interactions between costs, benefits, and their environment.

Given that the setting for this study is Australia, it is very likely that many large businesses have well established and fully compliant systems in place for their financial reporting. Without either compulsion or appropriate (business) benefits they will likely opt to remain committed to those systems rather than adopt SBR-based financial reporting. Considering institutional influence, when lodging financial reports in Australia, companies have to comply with the Corporations Regulations 2001. Section 1.0.07 General Requirements for Documents states: "Unless ASIC otherwise approves, a document to be lodged must: (a) be on white or light pastel colour paper: (i) of international A4 size; and (ii) of medium weight and good quality; and (b) be clearly printed or written in black or dark blue in a manner that is permanent and will make possible a reproduction, by photographic, computerised or other electronic means that is satisfactory to ASIC... " (Australian Government). While such regulation does not state that financial reports must be 
human readable, the wording of the regulations implies that human readability is necessary XBRL does not provide for human readability. Therefore, Australian XBRL filers who choose to lodge their financial reports via SBR, would still have to produce and lodge a PDF version of the reports to comply with the Company Regulations. Clearly, almost no company would lodge an XBRL and a PDF version of their financial reports when a PDF only ensures their compliance with lodgement requirements. In 2015 ASIC approved the lodgement of iXBRL financial reports only as a permissible alternative.

Remaining with institutional influence, stakeholders apparently concur that regulation would play a significant role in hastening SBR adoption. This stakeholder view seems to imply that SBR adoption is likely to languish without compulsion. Such compulsion, however, should take into account the supporting environment and organizational context, for example, the availability of affordable, firm-appropriate XBRL software. At present, accounting software in the Australian market suitable for small to medium enterprises (SME) does not appear to have XBRL functionality. For example, GovDirect a company providing software permitting SMEs to manage, process and submit Government obligations electronically, was no longer in operation as of 18 December 2015. While large businesses may have the wherewithal (if not the will) to lodge financial reports via SBR, compelling SMEs to use SBR without appropriate software is an untenable situation.

While prior studies appear to have dichotomized constructivist and ecological rationalities, our cluster analysis suggests that relationships apparently exist between constructivist and ecological rationalities. Ecological rationalities can influence organizational constructivist rationalities. For example, government engagement with businesses contemplating SBR adoption can help them to better understand the costs and benefits of SBR and create a more supportive environment. We also found that both institutional influences like mandatory policy and the provision of incentives can enhance the potential benefits of SBR adoption. This finding accords with organizing visions theory (Swanson \& Ramiller, 1997), whereby, key actors can help mobilize collective understanding of particular technologies or innovations via information diffusion.

Both rationalities cannot be separated from the characteristics of technologies. Further, technology context and characteristics (i.e., relative advantage, compatibility, and complexity) can act as either inhibiting or driving factors of IS adoption (Tornatzky \& Fleischer, 1990). Because SBR uses XBRL as the enabling technology, SBR's inherits characteristics such as being machine-readable, capable of solving interoperability issues between multiple systems, and capable of leveraging information via interactive data visualization (Perdana, Robb \& Rohde, 2015). Technological characteristics are among the contributing factors that interact with both constructivist and ecological rationalities. For example, the capability of SBR to deliver financial statements in interactive forms has the potential to increase performance expectancy. Additionally, because SBR can interact with multiple systems, the supporting environment such as technical infrastructure, market and consumer demand, and appropriate government policy are necessary to achieve optimal SBR adoption.

While in 2012 Australian Treasury released a SBR reporting Options Paper and received submissions from interested parties, aside from permitting iXBRL report lodgement in 2015, there has been silence ever since. We can only conclude that mandatory SBR reporting is no longer a high priority, and that the status quo will remain into the foreseeable future. However, should lodging financial reports via SBR become mandatory, constructivist and ecological 
rationalities or technological characteristics no longer figure in lodgement choice decision making. Imprudent mandatory policy, however, may impact negatively on perceptions of SBR and could inhibit the effective use of SBR in pursuing greater productivity. Further, an XBRL taxonomy that accommodates companies' needs, yet remains parsimonious, can increase the comparability of financial statements. Should the taxonomy be insufficient, the costs associated with implementing taxonomy extensions are likely to increase, conversely, however, the comparability of financial reports will likely decrease.

All of the aforementioned findings, that is, costs and benefits, the wherewithal related to finance, technology, and human resources, Corporations Regulations, and regulators have the potential to influence the adoption of SBR in Australia. One influence that should not be underestimated is the uniqueness of the Australian economy. Australia has an advanced, diverse, first-world economy, however, $97 \%$ of all businesses are small businesses. Further, $62 \%$ of small businesses are non-employing businesses and $75 \%$ of employing small businesses employ 1 to 4 employees (Treasury, 2016).

Having such a concentration of small (and micro) businesses has, at least, three effects on SBR adoption in Australia. First, the accounting software used by the majority of small businesses in Australia (e.g., MYOB and Reckon) almost certainly has no SBR capability, consequently, these small businesses have no means by which to access and use SBR-based financial reporting. Arguably, and somewhat contrary to SBR's raison d'etre, small businesses stand to benefit most from the reporting efficiencies offered by the 'recorded once, reported to many' benefits promoted by Treasury. Second, given the size of many small businesses there will be little, if any, demand from investors or other small businesses to compare the performance of such small businesses for, say, investment or financing purposes. Third, and related to small businesses' lower survival rates and volatile revenues, small businesses eschew using banks for debt finance, instead drawing on owners' household assets for financing (Connolly, Norman \& West, 2012). In short, given the characteristics of the Australian economy, that is, the high proportion of small businesses, the decision not to adopt SBR is an example of an entire section of the economy pursuing ecological rationality relative to SBR adoption.

Taken together, our analysis confirmed that SBR uptake in Australia is rather limited. While some stakeholders' predicted that the uptake rate was 12 percent per year, in reality, businesses using SBR for financial reporting account for only a tiny fraction of that figure. As the Australian Business Register's (ABR) Report of the Registrar notes for the period 2010-2013 "Activity statements, pay as you go reports and tax file number declarations lodged to the ATO accounted for the vast majority of SBR lodgements." For the 2014-2015 ${ }^{3}$ period the Report of the Registrar notes, "Along with its use for business-to-government transactions, SBR also underpins business-to-business transactions between employers and super funds under the SuperStream initiative." In both post-SBR reports there is no mention of numbers or trends relative to companies submitting financial reports via SBR, rather the reports focus on mandatory SuperStream reporting and lodgement of government forms, for example Business Activity Statements and Tax File Number Declarations.

Given the stated benefits of lodging SBR based financial reports, one might assume that Australian businesses are "radical non-adopters", however, when viewed in light of

${ }^{3}$ The 2014-15 Report of the Registrar is the most recent available on the Australian Business Register's website. 
constructivist and ecological rationalities in concert with the Australian economy's characteristics, Australian businesses' actions simply reflect both constructivist and ecological rationalities and their environment.

\section{Contributions and Limitations}

The findings from this study make three theoretical contributions to the current literature. First, our conceptualization guided by economics-based rationalities enriches our understanding of IS adoption. While prior literature has explored IS adoption, both from the economic-rationalistic and institutionalism perspectives, such perspectives have drawn criticism from the literature. In this current study, we show that IS adoption involves both constructivist and ecological rationality. Our findings show that organizations constructively develop their rationality based on the availability of information and resources. Organizations, however, may not simply consider costs and benefits of IS adoptions, but they are also adaptive to their environment. Our analysis of the text confirms this circumstance, whereby, the alignment between existing systems, government support, software availability, and the economic environment, more generally, contribute to the likelihood of SBR's uptake. Businesses' adaptation to the prevailing environment also appears to shape their economic considerations. We argue, therefore, that a focal point apparently exists between constructivist and ecological rationalities. Second, our findings reveal themes embedded in the 23 submissions to the Treasury reflecting our a priori categories of the coding scheme (see Research Method section). This finding indicates that the limited SBR adoption for financial reporting in Australia can be explained from constructivist and ecological rationality perspectives.

Third, we use the concept of organizational affordance to further explain the relationship between the two rationalities and SBR (non) adoption in Australia. Volkoff \& Strong (2013) suggest that affordances are generative mechanisms which may or may not cause an event. Organizational affordance offers organizations possibilities to use IS for their desired goals, however, if those goals are already achieved (e.g., compliance with regulations), further affordances' costs may outweigh any perceived benefits. Organizational affordance will not be actualized unless the organizations have the wherewithal, capability, and motivation to do so (Volkoff \& Strong 2013).

To illustrate, multiple jurisdictions and organizations have taken various approaches to implementing XBRL-enabled technologies. In Australia, for example, XBRL-enabled technologies were introduced as the backbone of SBR to reduce the cost burden of regulatory reporting on business. The Netherlands uses XBRL via SBR to streamline administration works and information exchange. Both are multi-purpose instantiations of XBRL-enabled technologies. In contrast, the US uses XBRL for financial report filing (10-K) only - a single purpose instantiation of XBRL-enabled technology. Similarly, the UK uses iXBRL for mandatory corporate tax filing to Her Majesty's Revenue and Customs (HMRC) as well as for optional filing of annual returns to Companies House. While XBRL can potentially afford multiple possibilities, organizations may not realize those possibilities unless they actualize their affordance with XBRL.

Following on from the three theoretical contributions, we offer the following practical contribution. We contend that considering ecological rationality can help progress SBR adoption in Australia. That is, we encourage actors to develop a shared understanding among 
stakeholders relative to SBR adoption in Australia. This shared understanding can heighten the legitimacy of SBR in Australia helping turn optimal adoption into reality to gain the intended benefits, particularly for SMEs. Further, well targeted incentives and ensuring that regulations governing lodgement of financial reports align with the aims of SBR could also help advance the SBR's uptake. For example, incentives could have been made available to developers to incorporate the SBR Taxonomy into popular SME accounting packages or the implied requirement for human-readable financial reports could have been revised at the outset of the SBR program.

Along with constructivist rationality and technological considerations, ecological rationality can help companies to substantiate and implement actions to adopt and use SBR. To illustrate, while the ability of XBRL-enabled technologies to streamline financial reporting and digital record-keeping is not in doubt, the implementation of XBRL in several jurisdictions remains challenging. For example, in France, a lack of institutional acceptance of XBRL implementations has helped undermine XBRL's wide-ranging abilities (Guilloux et al. 2013). In such circumstances, organizations may be reluctant to adopt XBRL-based technologies for fear of being left with a superseded technology. In contrast, the mandatory XBRL reporting policy in the US has unlocked multiple possibilities from XBRL use. Aside from facilitating financial report filing, XBRL can afford organizations more ready compliance with regulations, leverage the value of financial data via Business Intelligence and Analytics (BI\&A), enable interactive data and information visualizations (IDIV), and facilitate continuous auditing.

We acknowledge the limitations of this study. While the authors remain informed of the current status of SBR adoption in Australia, our interpretive case study relies on the data from 23 submission documents to the Australian Treasury. One might say that relying on these submissions alone may not generate a sufficiently broad palette of stakeholders' views. Several technological considerations that could impact SBR adoption such as security, trust and privacy issues were not exhibited in the submissions. Since security, trust and privacy are important in IS adoption decisions, future research could provide additional findings complementing this current research (Carter, Shaupp, Hobbs \& Campbell, 2011; Ali, Soar \& Yong, 2016). Future research may refine this study with broader data from multiple stakeholders (e.g., interviews, regulatory policy, and government documents). Undertaking interview or survey to multiple stakeholders involved in SBR adoption in Australia, for example, can provide insightful findings to complement or confirm this current research. Further, future research may also employ grounded theory method to provide more insightful findings relative to SBR adoption in Australia.

\section{Conclusion}

Whilst acknowledging the above limitation, there appears to be themes emerging relative to constructivist and ecological rationalities. In Australia, voluntary adoption of SBR-based financial reporting has not had its anticipated uptake. On the basis of cost - benefit analyses, from a constructivist rationality perspective, the case for SBR reporting appears quite attractive. To a large extent, however, Australian companies have not yet adopted SBRenabled financial reporting. It seems that satisfying the constructivist requirements of an adoption choice is not sufficient motivation to actually adopt a particular technology. Ecological rationality appears to play a substantial role in such adoption choices. In the case of SBR, it appears that without the right combination of the environmental, technological, and 
regulatory strategies, affordances, and incentives, companies make their own rational decisions not to adopt technologies. While the choice to mandate the use of technologies such as SBR remains with Governments, there still needs to be awareness that consideration must still be given to the aforementioned strategies, affordances, and incentives to ensure the desired adoption of the particular technology.

\section{References}

Ali, O., Soar, J., \& Yong, J. 2016. An investigation of the challenges and issues influencing the adoption of cloud computing in Australian regional municipal governments. Journal of Information Security and Applications, 27-28, 19-34.

Alles, M. \& Piechocki, M. (2012), Will XBRL improve corporate governance? A framework for enhancing governance decision making using interactive data. International Journal of Accounting Information Systems, 13(2). 91-108.

Australian Government (2001). Federal Register of Legislation. https://www.legislation.gov.au/Details/F2013C00529/Html/Volume_1\#_T oc362443230 Accessed: [22 February 2017].

Australia Government (2013), Report of the Registrar https://abr.gov.au/About-us/Report-ofthe-Registrar-previous-years/Report-of-the-Registrar-2012-13/Performance-andachievements/ Accessed: [19 April 2018]

Australia Government (2015), Report of the Registrar https://abr.gov.au/About-us/Report-ofthe-Registrar-previous-years/Report-of-the-Registrar-2014-15/Overview/ Accessed: [19 April 2018]

Azam, S., \& Taylor. D. (2011). Standard business reporting in Australia: Voluntary take-up issues facing users, preparers and regulators of company financial and business reports. Accountancy Business and Public Interest, 10(1), 16-41.

Azam, S., \& Taylor. D. (2016). Adopting Standard Business Reporting in Australia: Are CFOs persuaded by technology attributes? Malaysian Accounting Review, 12 (1), 27-54.

Baldwin, A.A., Brown, C. E. \& Trinkle, B. S. 2006. XBRL: An impacts framework and research challenge. Journal of Emerging Technologies in Accounting, 3, 97-116.

Carter, L., Shaupp, L.C., Hobbs, J., \& Campbell, R. 2011. The role of security and trust in the adoption of online tax filing. Transforming Government: People, Process and Policy, 5(4), 303-318.

Chatterjee, S., Moody, G., Lowry, P.B., Chakraborty, S., \& Hardin, A. (2015). Strategic relevance of organizational virtues enabled by information technology in organizational innovation. Journal of Management Information Systems, 32(3), 158-196.

Chen, Y-C. (2012). A comparative study of e-government XBRL implementations: The potential of improving information transparency and efficiency. Government Information Quarterly, 29 (4): 553- 563.

Chen, Y-C. (2013). Improving transparency in the financial sector: E-government XBRL implementation in the United States. Public Performance \& Management Review, 37(2): 241262. 
Compagni, A., Mele, V., \& Ravasi, D. (2015). How early implementations influence later adoptions of innovation: Social positioning and skill reproduction in the discussion of robotic surgery. Academy of Management Journal, 58(1), 242-278.

Connolly, E., Norman, D. \& West, T. (2012). Small Business: An Economic Overview. Reserve Bank of Australia. Available at: https://www.rba.gov.au/publications/workshops/other/small-bus-finround table-2012/pdf/small-bus-fin-roundtable.pdf [Accessed: February 2017]

Debreceny, R., Chandra, A., Cheh, J.J., Guithues-Amrhein, D., Hannon, N.J., Hutchison, P.D., Janvrin, D., Jones, R.A., Lamberton, B., Lymer, A., Mascha, M., Nehmer, R., Roohani, S., Srivastava, R.P., Travelsi, S., Tribunella, T., Trites, G., \& Vasarhelyi, M. A., (2005). Financial reporting in XBRL on the SEC's EDGAR system: a critique and evaluation. Journal of Information Systems, 19 (2), 191-210.

DiMaggio, P. J., \& Powell, W.W. (1983). The iron cage revisited: Institutional isomorphism and collective rationality in organizational fields. American Sociological Review, 48 (2): 147160 .

Dunne, T., Helliar, C., Lymer, A., \& Mousa, R. (2013). Stakeholder engagement in internet financial reporting: The diffusion of XBRL in the U.K. The British Accounting Review, 45 (3), 167-182.

Eisenhardt, K.M. (1989). Building theories from case study research. The Academy of Management Review, 14(4), 532-550.

European Banking Authority. (2013). Update on the technical standards on supervisory reporting requirements. Available at http://www.eba.europa.eu/-/update-on-thetechnical-standards-on-supervisory-reporting-requirements.

Fichman, R. G. (2004). Going beyond the dominant paradigm for IT innovation research: Emerging concepts and methods. Journal of the Association for Information Systems, 5(8), 314-355.

Garner, D., Henderson, D., Sheetz, S.D., \& Trinkle, B.S. (2013). The different levels of XBRL adoption. Management Accounting Quarterly, 14(2), 1-10.

Goodhue, D.L., \& Thompson, R.L. (1995). Task-technology fit and individual performance. MIS Quarterly 19(2): 213-236.

Goodhue, D. 1995. Understanding user evaluations of information systems. Management Science, 41(12), 1827-1844

Guilloux, V., Locke, J. \& Lowe, A. (2013). Digital business reporting standards: Mapping the battle in France. European Journal of Information Systems, 22 (3), 257-277.

Harris, T. S., \& Morsfield, S. (2012). An Evaluation of the Current State and Future of XBRL and Interactive Data for Investors and Analysts. Available at: https://www8.gsb.columbia.edu/

Hirschheim, R. (2007). Introduction to the special issue on "Quo Vadis TAM - Issues and reflections on technology acceptance research. Journal of the Association for Information Systems, 8(4): 203-205. 
Hodge, F.D., Kennedy, J.J \& Maines, L.A. (2004). Does search-facilitating technology improve the transparency of financial reporting. The Accounting Review 79(3): 687-703.

Janvrin, D., \& Mascha, M. F. (2010). The process of creating XBRL instance documents: A research framework. Review of Business Information Systems, 14(2), 11-34.

Janvrin, D. J., Pinsker, R.E., \& Mascha, M.F. (2013). XBRL-enabled, spreadsheet, or PDF? Factors influencing exclusive user choice of reporting technology. Journal of Information Systems, 27 (2), 35-49.

Kaganer, E., Pawlowski, S.D., \& Wiley-Patton, S. (2010). Building legitimacy for IT Innovations: The case of computerized physician order entry systems. Journal of the Association for Information Systems, 11(1), 1-33.

Klein, H. K. \& Myers, M. D. (1999). A Set of Principles for Conducting and Evaluating Interpretive Field Studies in Information Systems, MIS Quarterly, 23(1), 67-93.

Leonardi, P.M. (2007). Activating the informational capabilities of information technology for organizational change. Organization Science, 18(5), 813-831.

Leonardi, P.M. (2011). When flexible routines meet flexible technologies: Affordance, constraint, and the imbrication of human and material agencies. MIS Quarterly, 35(1), 147-167.

Levin, Y., \& Aharon, I. (2014). Emotion, utility maximization, and ecological rationality. Mind and Society, 13, 227-245.

Majchrzak, A \& Markus, M. L. (2012). Technology affordances and constraints in management information systems.In: Kessler, E. (Ed.), Encyclopedia of Management Theory. Sage Publications, Thousand Oaks.

Markus, M. L., \& Silver, M.S. (2008). A foundation for the study of IT effects: A new look at DeSanctis and Poole's concepts of structural features and spirit. Journal of the Association for Information Systems, 9(10), Article 5.

McGraw, K.O., \& Wong, S.P. (1996). Forming inferences about some intraclass correlation coefficients. Psychological Methods, 1(1), 30-46.

Mignerat, M., \& S. Rivard. (2009). Positioning the institutional perspective in information systems research. Journal of Information Technology, 24 (4): 369-391.

Mills, A.J., Durepos, G., \& Wiebe, E. (2010). Encyclopedia of case study research. London: Sage.

Muthusamy, K. Bir, P. \& Birt, J. (2017). XBRL and the qualitative characteristics of useful financial information. Accounting Research Journal, 30 (1): 107-126.

Nagy, J., Jubb, C., Rouse, A. \& Cybulski, J. (2008). SBR/XBRL: a hot topic internationally with rising local prominence. Deakin Business Review, 1 (2): 15.21.

Nickerson, J.V., \& Muehlen, M. (2006). The ecology of standards processes: Insights from Internet Standard Making. MIS Quarterly 30, 467-488.

Nielsen, J. A., L. Mathiassen, \& S. Newell. (2014). Theorization and translation in information technology institutionalization: Evidence from Danish home care. MIS Quarterly 38 (1): 165-186. 
North, D.C. (1990). Institutions, Institutional Change and Economic Performance, Cambridge, Cambridge University Press

Perdana, A., Robb, A. \& Rohde, F. (2015). An integrative review and synthesis of XBRL research in academic journals. Journal of Information Systems, 29 (1): 115-153.

Robb, D., Rohde, F. \& Green, P (2016) Standard Business Reporting in Australia: efficiency, effectiveness, or both? Accounting \& Finance, 56 (2): 509-544.

Seidel, S; Recker, J; \& vom Brocke, J. (2014). Sensemaking and sustainable practicing: functional affordances of information systems in green transformations, MIS Quarterly, 37(4), 1275-1299.

Shrout, P.E., \& Fleish, J.L. (1979). Interclass correlations: Uses in assessing rater reliability. Psychological Bulletin, 86(2): 420-428.

Smith, V.L. (2003). Constructivist and Ecological Rationality in Economics. The American Economic Review, 93 (3): 465-508.

Smith, V.L. (2008). Rationality in Economics: Constructivist and Ecological Forms. UK: Cambridge University Press.

Steenkamp, L.P. \& Nel, G.F. (2012). The adoption of XBRL in South Africa: An empirical study. The Electronic Library, 30(3), 409 - 425.

Stendal, K., Thapa, D., \& Lanamäki, A. (2016). Analyzing the concept of affordances in information systems. In $20164^{\text {th }}$ Hawaii International Conference on System Sciences (HICSS), IEEE: 5270-5277.

Swanson, E. B., \& Ramiller, N.C. (1997). The organizing vision in information systems innovation. Organization Science, 8 (5): 458-474.

Teo, H.H., Wei, K.K., \& Benbasat, I. (2003). Predicting intention to adopt interorganizational linkages: An institutional perspective. MIS Quarterly 27(1), 19-49.

The Treasury. (2012). Use of Standard Business Reporting for Financial Reports. Australian Government. Available at http://www.treasury.gov.au/ConsultationsandReviews/Consultations/20 12/SBR-Options-Paper [Accessed: 22 February 2017]

The Treasury. (2016). National Small Business Statistics. Release Date: 23 September 2016. Australian Government. Available at http://www.treasury.gov.au/PublicationsAndMedia/Publications/2012/s ml-bus-data [Accessed: 1 February 2017]

Thornton, P. H., Ocasio, W., \& Lounsbury, M. (2012). The Institutional Logics Perspective: A New Approach to Culture, Structure, and Process. New York, NY: Oxford University Press.

Tornatzky, L., \& Fleischer, M. (1990). The Process of Technology Innovation. Lexington: Lexington Books.

Troshani, I., Paker, L.D., \& Lymer, A. (2015). Institutionalising XBRL for financial reporting: resorting to regulation, Accounting and Business Research, 45(2), 196-228.

US Security and Exchange Commission. (2016). Structured disclosure at the sec: history and rulemaking. Available at https://www.sec.gov/page/osdhistoryandrulemaking. 
Valentinetti, D. \& Rea, M. (2012). IFRS taxonomy and financial reporting practices: The case of Italian listed companies. International Journal of Accounting Information Systems, 13(2), 163180.

Vasarhelyi, M. A., Chan, D. Y. \& Krahel, J. P. (2012). Consequences of XBRL standardization on financial statement data, Journal of Information Systems, 26(1), 155-167.

Venkatesh, V., Morris, M.G., Davis, G.B., \& Davis, F.D. (2003). User acceptance of information technology: toward a unified view. MIS Quarterly, 27(3), 425-478.

Volkoff, O., \& Strong, D.M. (2013). Critical realism and affordance: Theorizing IT-associated organizational change processes. MIS Quarterly, 37(3), 819-834.

Zammuto, R.F., Griffith, T.L., Majchrzak, A., Dougherty, D.J., \& Faraj, A. (2007). Information technology and the changing fabric of organization. Organization Science, 18(5), 749-762. 
Appendix A: Sentiments and views towards SBR adoption by stakeholder type

\begin{tabular}{|c|c|c|c|c|c|}
\hline & \multicolumn{5}{|c|}{ Sentiment/Views } \\
\hline Category & $\begin{array}{l}\text { Accounting } \\
\text { Firms }\end{array}$ & Companies & $\begin{array}{l}\text { Professional } \\
\text { Bodies }\end{array}$ & Developers & Individuals \\
\hline \multicolumn{6}{|l|}{$\begin{array}{l}\text { Constructivist } \\
\text { Rationality }\end{array}$} \\
\hline $\begin{array}{l}\text { Performance } \\
\text { Expectancy }\end{array}$ & Positive & $\begin{array}{l}\text { Cautiously } \\
\text { Positive/ }\end{array}$ & Positive & & \\
\hline \multirow[b]{2}{*}{$\begin{array}{l}\text { Effort } \\
\text { Expectancy }\end{array}$} & & $\begin{array}{l}\text { Cost } \\
\text { Concerns }\end{array}$ & & & \\
\hline & Positive & $\begin{array}{c}\text { Cautiously } \\
\text { Positive/ } \\
\text { Cost } \\
\text { Concerns }\end{array}$ & Positive & & \\
\hline \multicolumn{6}{|l|}{$\begin{array}{l}\text { Ecological } \\
\text { Rationality }\end{array}$} \\
\hline $\begin{array}{l}\text { Supporting } \\
\text { environment }\end{array}$ & $\begin{array}{l}\text { Supportive/ } \\
\text { Advocate } \\
\text { Engagement } \\
\text { Strategy }\end{array}$ & & $\begin{array}{l}\text { Supportive/ } \\
\text { Advocate } \\
\text { Engagement } \\
\text { Strategy }\end{array}$ & & \\
\hline \multirow[t]{2}{*}{$\begin{array}{l}\text { Institutional } \\
\text { Influence }\end{array}$} & $\begin{array}{l}\text { Cautiously } \\
\text { Positive/ }\end{array}$ & & & $\begin{array}{c}\text { Cautiously } \\
\text { Positive/ }\end{array}$ & $\begin{array}{c}\text { Cautiously } \\
\text { Positive/ }\end{array}$ \\
\hline & $\begin{array}{l}\text { Mandate } \\
\text { recommended }\end{array}$ & & & $\begin{array}{l}\text { Mandate } \\
\text { recommended }\end{array}$ & $\begin{array}{l}\text { Mandate } \\
\text { recommended }\end{array}$ \\
\hline $\begin{array}{l}\text { Organizational } \\
\text { Context }\end{array}$ & & $\begin{array}{c}\text { Discern } \\
\text { between } \\
\text { large/small } \\
\text { companies }\end{array}$ & $\begin{array}{c}\text { Discern between } \\
\text { large/small } \\
\text { companies }\end{array}$ & & \\
\hline $\begin{array}{l}\text { Technological } \\
\text { Characteristics }\end{array}$ & $\begin{array}{l}\text { Technology } \\
\text { well-suited }\end{array}$ & & $\begin{array}{c}\text { Technology } \\
\text { well- } \\
\text { suited/better } \\
\text { explain benefits }\end{array}$ & & $\begin{array}{l}\text { Technology } \\
\text { well-suited }\end{array}$ \\
\hline $\begin{array}{l}\text { Organizational } \\
\text { Affordance/ } \\
\text { Use of IS }\end{array}$ & $\begin{array}{l}\text { Cautiously } \\
\text { positive/ } \\
\text { taxonomy } \\
\text { sufficiency } \\
\text { concerns }\end{array}$ & $\begin{array}{l}\text { Potentially } \\
\text { negative/ } \\
\text { cost and } \\
\text { usefulness } \\
\text { concerns }\end{array}$ & $\begin{array}{c}\text { Cautiously } \\
\text { positive/ better } \\
\text { explain benefits }\end{array}$ & & \\
\hline
\end{tabular}

The various stakeholders' views reflect their roles relative to SBR and, to some extent, are likely are somewhat self-serving. For example, the accounting firms and professional bodies are generally view SBR's adoption and possible mandatory use as 
positive. The accounting firms and professional bodies both note the benefits to financial reporting transparency and efficiency. Companies' concerns, naturally enough, center on costs of software and staff upgrades, and that they, in fact, comply with current regulations. The developers, generally, advocate mandatory SBR reporting because their development efforts, from an investment perspective, become less risky. The individual's views were from an academic perspective, accordingly they expressed confidence in the technology and that making SBR reporting mandatory, on balance, was desirable. Overall, these views broadly align with Robb et al.'s (2016) study on Australian SBR adoption.

Copyright: () 2018 Perdana, Robb, Rohde \& Birt. This is an open-access article distributed under the terms of the Creative Commons Attribution-NonCommercial 3.0 Australia License, which permits non-commercial use, distribution, and reproduction in any medium, provided the original author and AJIS are credited.

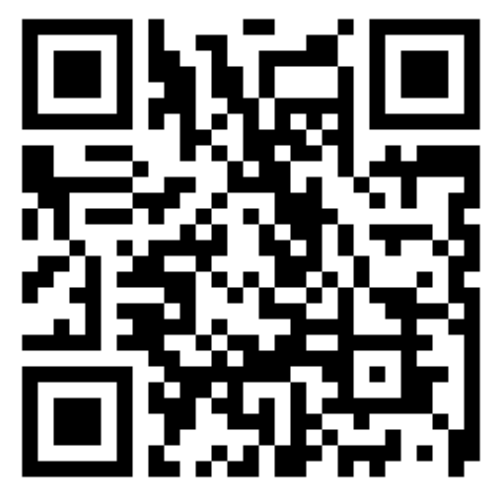

